\title{
Antibacterial and Antioxidant Activity of Black Mulberry (Morus nigra L.) Extract for Acne Treatment
}

\author{
Arif Budiman $^{1 *}$, Diah Lia Aulifa ${ }^{2}$, Arif Satria Wira Kusuma ${ }^{1}$, Astri Sulastri ${ }^{1}$
}

Arif Budiman ${ }^{1 *}$, Diah Lia Aulifa $^{2}$, Arif Satria Wira Kusuma ${ }^{1}$, Astri Sulastri ${ }^{1}$

'Departement of Pharmaceutical and Technology Pharmacy, Universitas Padjadjaran Jatinangor, INDONESIA.

${ }^{2}$ Sekolah Tinggi Farmasi Indonesia, JI. Soekarno Hatta No. 354, Bandung, INDONESIA.

\section{Correspondence}

Arif Budiman, Departement of Pharmaceutical and Technology Pharmacy, Universitas Padjadjaran, Jatinangor, INDONESIA.

Tel.: 45363 Telp/Fax: 022-7796200

E-mail: arif.budiman@unpad.ac.id

History

- Submission Date: 14-03-2017;

- Review completed: 28-03-2017

- Accepted Date: 30-05-2017

DOI : 10.5530/pj.2017.5.97

Article Available online

http://www.phcogj.com/v9/i5

\section{Copyright}

(C) 2017 Phcog.Net. This is an openaccess article distributed under the terms of the Creative Commons Attribution 4.0 International license.

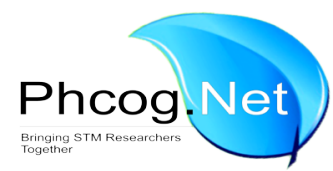

\begin{abstract}
Introduction: Black mulberry is rich in phenols and is hence usable in the treatment of acne. It also contains anthocyanin, a well-known antioxidant. This study aimed to examine the antibacterial and antioxidant properties of black mulberry (Morus nigra L.) extract as a potential raw material for use in beauty care products. Method: Fruit extract was obtained using maceration method with $96 \%$ ethanol. The antibacterial activity of the extract was determined by disc diffusion method, while the minimal inhibitory concentration (MIC) and minimum bactericidal concentration (MBC) were determined by microdilution method. Furthermore, the antioxidant activity of the extract was tested by DPPH method. Result: The results showed a $2.5 \% \mathrm{MIC}$ against $S$. epidermidis and $P$. acnes, confirming the antibacterial activity of black mulberry extract. The MBC values for the respective bacterium were $2.5 \%$ and $5 \%$. Regarding antioxidant activity, the $\mathrm{IC}_{50}$ value of black mulberry extract was $146.731 \mathrm{mg} / \mathrm{mL}$, suggesting its medium potential. Conclusion: Morus nigra extract has antibacterial activity against $S$. epidermidis and $P$. acnes, and has medium potential as antioxidant.

Key words: Morus nigra extract, Antioxidant, Anti acne, Staphylococcus epidermidis, Propionibacterium acnes.
\end{abstract}

\section{INTRODUCTION}

Our skin protects the body from environmental influences such as ultraviolet rays of the sun and numerous microbes. ${ }^{1}$ A notable influence of the environment on our skin is premature aging and acne. Premature aging is usually caused by frequent exposure to ultraviolet rays. ${ }^{2}$ Ultraviolet rays can cause skin burn ${ }^{3}$ and trigger the formation of free radicals more quickly.

Acne is an inflammatory disease of the skin that often occurs in adolescence. ${ }^{5,6}$ One of the factors that cause acne on face is due to the activity of bacteria. Propionibacterium acnes and Staphylococcus epidermidis, the two normal skin flora, are often isolated from lesions of acne $^{7}$.

Black mulberry (Morus nigra) contains the highest total phenolic compounds compared to the species of another genus Morus and has antibacterial and antioxidant activity. ${ }^{8,9} 2$-arylbenzofuran (Moracin M) has known antibacterial activity against Streptococcus faecalis (MBC $500 \mu \mathrm{g} / \mathrm{mL}$ ), and oxyresveratrol stilbenoid against Staphylococcus aureus (MBC $125 \mu \mathrm{g} / \mathrm{mL}$ ). ${ }^{10}$ Mulberry fruits are a rich source of flavonoids and anthocyanin compounds as antioxidant. ${ }^{9,11,12}$

\section{MATERIALS AND METHOD}

\section{Materials}

The materials used in this study consisted of Black Mulberry fruit obtained from Plantations in Cibodas, Maribaya-Lembang, 1.1-diphenyl-2-picrylhydrazyl
(DPPH) (Sigma Aldrich), glycerin (Brataco Chemical), hydroxypropyl methylcellulose (HPMC) (Brataco Chemical), Mueller Hinton Agar (Merck), Mueller Hinton Broth (Merck), saline (Otsu-NS), ethanol 96\% (CV Sarana Abdi Bakti), Dimethyl Sufoxide (DMSO) (Merck), P. acnes and S. epidermidis bacteria from the Laboratory of Microbiology, Faculty of Pharmacy University of Padjadjaran.

The tools used in this study is the incubator (Yenaco), magnetic stirrer (Yellow-MAG HS7), mechanical stirrer (IKA EUROSTAR), micropipette (Socorex), ovens, pH meters (108 pH ATC), analytical balance (OHAUS TM-Adventure), Viscometer Rion (VT 04F), UV-Vis Spectrophotometry Analytik Jena Specord.

\section{Extraction}

Black mulberry was dried to a final weight of $10 \mathrm{~kg}$ in an oven at a temperature of $50^{\circ} \mathrm{C}^{13,14}$ and extracted by maceration method using $96 \%$ solvent ethanol twice for 24 hours at room temperature. A viscous extract was obtained using a rotatory evaporator under vacuum at $50^{\circ} \mathrm{C}$.

\section{Phytochemical Screening}

Phytochemical screening of ethanol extract Black Mulberry fruit (Morus nigra) was tested for the presence of alkaloids, steroids/ triterpenoids, saponins, 
polyphenols, tannins, flavonoids, quinones, monoterpenoid, and sesquiterpenoids.

\section{Antibacterial activity}

The antibacterial activity was tested by disc diffusion method. The growth medium used was Mueller Hinton Agar. Firstly, the extract was dissolved in $0.01 \%$ DMSO to obtain four concentrations: $10 \%, 20 \%, 40 \%$, and $80 \%$. A $6 \mathrm{~mm}$ diameter paper disc was soaked in $5 \mathrm{~mL}$ of the extract for 15 minutes and then dried in a laminar flow cabinet for 2 hours. The paper discs were then placed on the surface of the media containing inoculated bacteria. The Petri dishes were incubated at $37^{\circ} \mathrm{C}$ for 18 hours $^{15,16}$.

\section{Determination of MIC and $M B C$}

MIC and MBC were determined by micro-dilution method using a microplate ${ }^{17} .100 \mathrm{~mL}$ MHB media added into $100 \mu \mathrm{L}$ of extract. Furthermore, each well was added $10 \mathrm{~mL}$ of the bacterial suspension was adjusted to $0.5 \mathrm{McF}$ arland standards. Furthermore, the microplate was covered with a plastic wrap and then incubated at $37^{\circ} \mathrm{C}$ for 18 hours.

\section{Antioxidant activity}

The antioxidant activity of the extract was measured based on its scavenging activity of 1-diphenyl 2-picrylhyorazyl (DPPH) free radicals according to the method described previously ${ }^{18}$ with slight modifications. One milliliter of $0.1 \mathrm{mM}$ DPPH solution in methanol was mixed with $1 \mathrm{ml}$ of plant extract of varying concentrations $(100,120,140,160$, and $180 \mu \mathrm{g} / \mathrm{mL}$ ).

\section{Sample solution}

The DPPH solution (2:3) was allowed to stand for the operating time to read absorbance at the maximum wavelength. A mix of $1 \mathrm{ml}$ methanol and $1 \mathrm{ml} \mathrm{DPPH}$ solution was used as the control. Corresponding blank samples were prepared and L-ascorbic acid $(1-100 \mu \mathrm{g} / \mathrm{ml})$ was used as a reference standard. The reaction was carried out in triplicate, and the decrease in absorbance was measured at $517 \mathrm{~nm}$ after 30 minutes in the dark using a UV-Vis spectrophotometer. Absorbance values were expressed as a percentage of its inhibition $\left(\mathrm{IC}_{50}\right)$ using the equation:

$\%$ Inhibition $=\left[1-\left(\mathrm{A}_{\text {sample }} / \mathrm{ADPPH}\right)\right] \times 100$

Where

$\%$ Inhibition

A sample $_{\text {, }}$

$\mathrm{A}_{\mathrm{DPPH}}$

$=$ percentage of free radical inhibition capacity

$=$ absorbance of sample

$=$ absorbance of DPPH control

$\mathrm{IC}_{50}$ value of the sample was obtained by entering a value of 50 into the equation of each sample.

\section{RESULTS AND DISCUSSION}

\section{Plant determination}

Based on the records available at the Department of Biological Science of Universitas Padjadjaran, the plants used in the research were identified as Morus nigra L.

\section{The drying and Extraction}

The purplish black color of black mulberry is due to anthocyanin compounds present in it. These compounds have been found to remain stable in the acidic atmosphere $(\mathrm{pH}<5)$ at $50^{\circ} \mathrm{C}$, so the drying temperature should not be more than $50^{\circ} \mathrm{C} .{ }^{20}$ The maceration process was limited to $2 \times 24$ hours to obtain maserat of consistent color from black mulberry. According to previous study, ${ }^{21}$ the highest antioxidant compound of morus nigra extracts can be found in a polar solvent. Extraction process using ethanol $96 \%$ ca attract secondary compounds from botanicals.
Ethanol often used to attract the antioxidant compounds in fruit extracts such as anthocyanin. $22,23,24$

\section{Phytocemicals screening}

The results of phytochemical screening showed can be seen in Table 1.

Using phytochemical screening, we detected flavonoids and phenolics in black mulberry. ${ }^{25,26}$ The presence of anthocyanin was also identified, which gives the extract of black mulberry the characteristic violet color, ${ }^{27}$ According to previous study, ${ }^{28}$ the contains of the phytochemical black mulberry extract ethanol compound will be easier to be detected. The antibacterial activity of morus nigra extract can be seen in Table 2.

The Results of MIC and MBC of Morus nigra Ethanol Extract can be seen in Table 3.

Based on our results, the MIC value of black mulberry extract against S. epidermis was in the range of $1.25-2.5 \%$, while the MIC value against

\section{Table 1: The Results of Phytochemical Screening of Morus nigra Extract}

\begin{tabular}{cc|}
\hline Secondary metabolic & $\begin{array}{c}\text { Black Mulberry Fruit (Morus } \\
\text { nigra) Ethanol Extract }\end{array}$ \\
\hline Alkaloid & - \\
Flavonoid & + \\
Polyphenols & + \\
Tannin & + \\
Monoterpenoids and sesquiterpenoids & + \\
Steroid and triterpenoid & - \\
Quinone & - \\
Saponin & - \\
\hline
\end{tabular}

$+=$ presence, $-=$ absence

\section{Table 2: Antibacterial activity}

\begin{tabular}{ccc|}
\hline Extract Concentration $(\% \mathrm{~b} / \mathrm{v})$ & \multicolumn{2}{c|}{ Inhibition Zone Diameter $(\mathrm{mm})$} \\
\cline { 2 - 3 } & S. epidermidis & P. acnes \\
\hline 10 & $6.50 \pm 2.19$ & 0 \\
20 & $12.28 \pm 2.82$ & $5.81 \pm 2.64$ \\
40 & $15.33 \pm 0.61$ & $11.28 \pm 1.29$ \\
80 & $19.46 \pm 1.86$ & $15.12 \pm 1.50$ \\
Solvent control DMSO 0.01\% & 0 & 0 \\
\hline
\end{tabular}

MIC and MBC of Extracts Black Mulberry Fruit (Morus nigra)

Table 3: The Results of MIC and MBC of Morus nigra Ethanol Extract

\begin{tabular}{ccc}
\hline Extract Concentration $(\% \mathrm{~b} / \mathrm{v})$ & \multicolumn{2}{c}{ The Growth of Bacteria } \\
\cline { 2 - 3 } & P. acnes & S. epidermidis \\
\hline 20 & - & - \\
10 & - & - \\
5 & - & - \\
2.5 & + & - \\
1.25 & + & + \\
0.625 & + & + \\
0.3125 & + & + \\
0.156 & + & + \\
0.078 & + & + \\
Media Control MHB & - & - \\
Bacteria Control & + & + \\
Extract Control & - & - \\
\hline
\end{tabular}




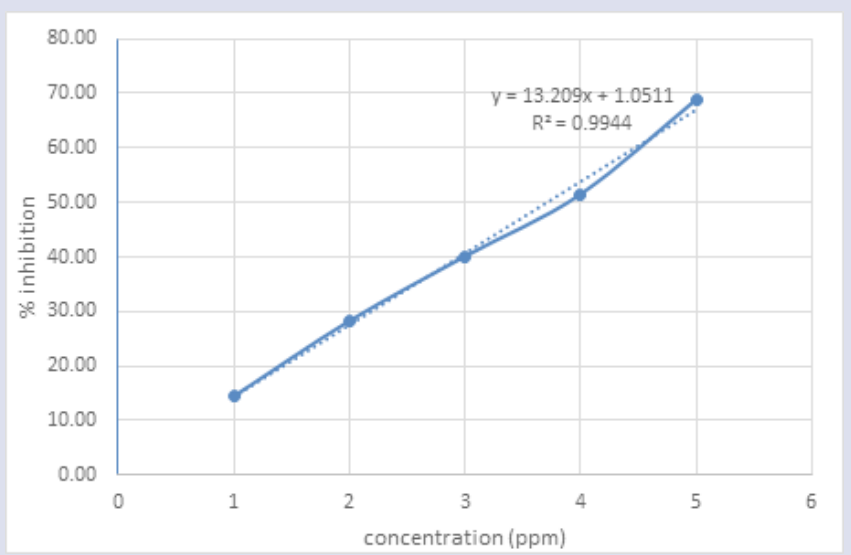

Figure 1: Relationship between concentrations of vitamin $C$ and percentage inhibition of DPPH

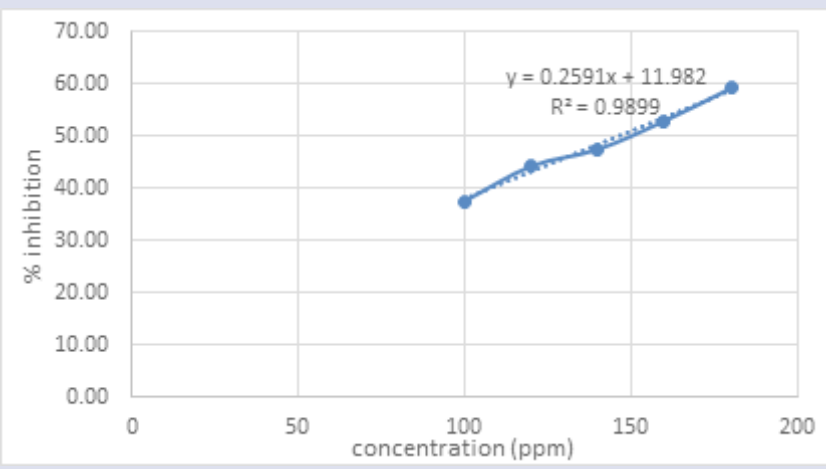

Figure 2: Relationship between concentrations of black mulberry extract and percentage of inhibition of DPPH

$P$. acnes was in the range of $2.5-5 \%$. The MBC value of black mulberry against $S$. epidermis was $2.5 \%$, while that against $P$. acnes was $5 \%$. We can conclude from the above findings that the ethanol extract of black mulberry has excellent antibacterial activity against S. epidermis and P. acnes at a concentration of $2.5 \%$.

\section{Antioxidant activity}

The antioxidant activity test based on DPPH method is one of the most common methods for preliminary testing of plant extracts. ${ }^{29,30}$ This method is most suitable for polar compounds such as anthocyanins because the DPPH crystals can easily dissolve in a commonly available solvent and give maximum absorbance.

According to previous study, ${ }^{31}$ the antioxidant activity using ethanol $96 \%$ has the value of $\%$ inhibition is the highest compared with other solvents. This method can be applied to the antioxidant compound that is hydrophilic and lipophilic. ${ }^{32}$

Relationship between concentrations of vitamin $\mathrm{C}$ and percentage inhibition of DPPH can be seen in Figure 1.

These graphs show that the $\mathrm{IC}_{50}$ of a solution of vitamin $\mathrm{C}$ is 3.7057 . According previous study ${ }^{33}$, an antioxidant is considered to be very powerful if its $\mathrm{IC}_{50}<50 \mathrm{mg} / \mathrm{mL}$. The hydrogen atom in the hydroxyl group binds to free radicals, thus increasing the stability of free radicals. Vitamin C has four hydroxyl groups and so its antioxidant activity is considered to be very powerful. These hydroxyl groups can give electrons to free radicals.

Relationship between concentrations of black mulberry extract and percentage of inhibition of DPPH can be seen in Figure 2.
In our study, the $\mathrm{IC}_{50}$ of black mulberry extract was $146.731 \mu \mathrm{g} / \mathrm{mL}$, falling in the range of $\mathrm{IC}_{50}$ values of $100-250 \mu \mathrm{g} / \mathrm{mL}$ for antioxidants. ${ }^{33}$ Anthocyanins from black mulberry extract in $96 \%$ ethanol yielded an $\mathrm{IC}_{50}$ value of $1.2 \mathrm{mg} / \mathrm{L}$. Factors that may cause differences include different varieties of black mulberry used, use of different solvents for extraction, and use of different DPPH. Anthocyanin in black mulberry is the reason for its greatest antioxidant activity. ${ }^{32}$

The extract of black mulberry has antioxidant activity that is 39.5 times lower than that of a solution of vitamin C. The reason being that an extract of black mulberry contains not only anthocyanin's but also numerous other secondary metabolites that could not work as hard as vitamin $\mathrm{C}$, which is a pure antioxidant compound.

\section{CONCLUSION}

Black mulberry fruit extracts have antibacterial activity with MIC value of by $2.5 \%$ against the bacteria S. epidermis and P. acnes . Black mulberry fruit extracts have antibacterial activity with $\mathrm{MBC}$ value for each bacterium was $2.5 \%$ and $5 \%$. Black mulberry fruit extracts has medium potential antioxidant activity with IC50 value is $146.731 \mathrm{mg} / \mathrm{mL}$.

\section{ACKNOWLEDGEMENT}

The Authors thanks to Universitas Padjadjaran for financial support in this research.

\section{CONFLICT OF INTEREST}

The authors declare that there is no conflict of interest, financial, or otherwise regarding the publication of this paper.

\section{ABBREIATIONS USED}

MIC: Minimal inhibitory concentration; MBC: Minimum bactericidal concentration; DPPH: 1.1-diphenyl-2-picrylhydrazyl; MHA: Mueller Hinton Agar; MHB: Mueller Hinton Broth; DMSO: Dimethyl sulfoxide.

\section{REFERENCES}

1. Dermawan AM, Kusharyanti PDL. Efektivitas krim anti jerawat ekstrak metanol daun pacar air (Impatiens balsamina L.). Traditional Medicine Journal. 2015;20(3):127-33

2. Yaar, Gilchrest AB. Aging of Skin (7th ed.) New York: McGraw-Hill. 2008.

3. Lakshmi T, Radha MR, Jayshree N. Formulation and Evaluation of Herbal Gel Conatining Dalbergia sissoo Roxb. Bark Extract. Journal of Pharmaceutical Research \& Clinical Practice. 2014;4(1):53-7.

4. Cadet J, Wagner JR. DNA base damage by reactive oxygen species, oxidizing agents, and UV radiation. Cold Spring Harbor Perspectives in Biology. 2013;5.2 a012559. doi: 10.1101/cshperspect.a012559. https://doi.org/10.1101/cshperspect.a012559.

5. Kurokawa I, et al. New developments in our understanding of acne pathogenesis and treatment. Experimental dermatology. 2009;18(10):821-32. DOI:10.1111/ j.1600-0625.2009.00890.x https://doi.org/10.1111/j.1600-0625.2009.00890.x.

6. Zaenglein AL, Thiboutot DM. Acne vulgaris. Dermatology. London: Mosby. 2003;53144.

7. Nakase K. et al. Relationship between the severity of acne vulgaris and antimicrobial resistance of bacteria isolated from acne lesions in a hospital in Japan. Journal of Medical Microbiology. 2014;63(5):721-8. DOI 10.1099/jmm.0.067611-0. https://doi.org/10.1099/jmm.0.067611-0.

8. Sofia PG, et al. Chemical characterisation of white (Morus alba), and black (Morus nigra) mulberry fruits. J. Horticultural Fore Biotech. 2014;18(3):133-5.

9. Radojkovic MM, et al. Free radical scavenging activity and total phenolic and flavonoid contents of mulberry (Morus spp. L., Moraceae) extracts. Hemijska industrija. 2012;66.4:547-52. doi: 10.2298/HEMIND111111002R.

10. Majinda RRT, Mazimba O, Motlhanka D. Antioxidant and antibacterial constituents from Morus nigra. 2011.

11. Arabshahi-Delouee $S$, Urooj A. Antioxidant properties of various solvent extracts of mulberry (Morus indica L.) leaves. Food Chemistry. 2007;102(4):1233-40. http://dx.doi.org/10.1016/j.foodchem.2006.07.013.

12. Chen M, Xia L, Xue P. Enzymatic hydrolysis of corncob and ethanol production from cellulosic hydrolysate. International Biodeterioration \& Biodegradation. 2007;59(2):85-9. http://dx.doi.org/10.1016/j.ibiod.2006.07.011. 
13. Phoungchandang $S$, Tochip $L$, Srijesdaruk V. White mulberry leaf drying by tray and heat pump dehumidified dryers. World J Agric Sci. 2008;4(5):844-51.

14. Butkhup L, Khanprom I, Samappito S. Influence of the Drying Process on Flavonoid Contents and Their Effects on Antioxidant Activity of Mulberry (Morus alba L.) Green Tea Production. 2007.

15. Budianto B, Prajitno A, Yuniarti A. Aktivitas Antibakteri Ekstrak Buah Adas (Foeniculum Vulgare, Mill) Pada Vibrio Harveyi Dan Vibrio alginolyticus Antibacteria Activity of Fennel (Foeniculum vulgare Mill) Extract on Vibrio alginolyticus and Vibrio harveyi. Jurnal Agritech. 2015;35(03):266-72. https://doi.org/10.22146/ agritech.9336

16. Basri DF, et al. The potential of aqueous and acetone extracts of galls of Quercus infectoria as antibacterial agents. Indian Journal of Pharmacology. 2005;37(1):26. DOI: 10.4103/0253-7613.13851. https://doi.org/10.4103/02537613.13851.

17. Yigit $D$, Yigit N. Antibacterial Activty Of Black MulberrY (Morus nigra) Fruits and Leaves. EÜFBED - Fen Bilimleri Enstitüsü Dergisi Cilt-Sayı. 2008;1(1):39-47.

18. Brand-Williams W, Cuvelier ME, Berset C. Use of free radical method to evaluate antioxidant activity. Lebensm Wiss Technology. 1995;28:25-30. https://doi. org/10.1016/S0023-6438(95)80008-5

19. Sahu RK, Kar M, Routray R. DPPH free radical scavenging activity of some leafy vegetables used by tribals of odisha. India J Med Plants. 2013;1(4):21-7.

20. LI J, et al. Isolation and expression analysis of anthocyanin biosynthetic genes in Morus alba L. Biologia Plantarum. 2014;58(4):618-26. DOI: 10.1007/s10535014-0450-5

21. Minhas MA, et al. Evaluation of Antibiotic and Antioxidant Activity of Morus nigra (Black Mulberry) Extracts Against Soil Borne, Food Borne and Clinical Human Pathogens. Pakistan J Zool. 2016;48(5):1381-8.

22. Ercisli S, Orhan E. Chemical composition of white (Morus alba), red (Morus rubra) and black (Morus nigra) mulberry fruits. Food Chemistry. 2007;103(4):1380-4 http://dx.doi.org/10.1016/j.foodchem.2006.10.054.

23. Pawlowska AM, Oleszek W, Braca A. Quali-quantitative analyses of flavonoids of Morus nigra L. and Morus alba L.(Moraceae) fruits. Journal of Agricultura and Food Chemistry. 2008;56(9):3377-80. DOI: 10.1021/jf703709r; https://doi org/10.1021/jf703709r.

\section{GRAPHICAL ABSTRACT}

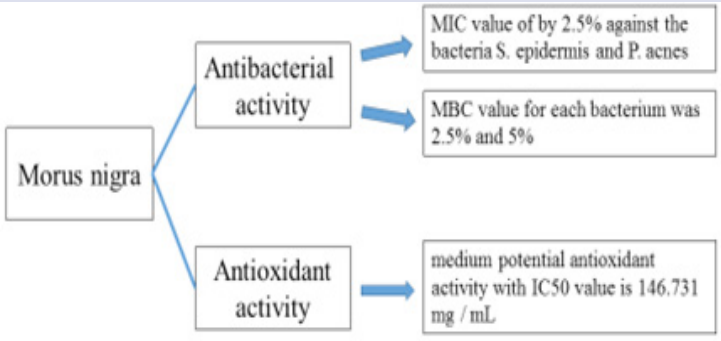

24. Dkhil MA, Bauomy AA, Diab MS, Al-Quraishy S. The antioxidant effect of Morus alba leaves extract on kidney, testes, spleen and intestine of mice. Pakistan $J$ Zool. 2015;47(2):393-7.

25. Özgen M, Serçe S, Kaya C. Phytochemical and antioxidant properties of anthocyanin-rich Morus nigra and Morus rubra fruits. Scientia Horticulturae. 2009;119(3):275-9. http://dx.doi.org/10.1016/j.scienta.2008.08.007.

26. Suh $\mathrm{HJ}$, et al. Thermal kinetics of color degradation of mulberry fruit extract. Molecular Nutrition and Food Research. 2003:47(2):132-5. DOl: 10.1002/food. 200390024 https://doi.org/10.1002/food.200390024

27. Wang $\mathrm{H}$, Cui Y, Zhao C. Flavonoids of the genus Iris (Iridaceae). Mini Reviews in Medicinal chemistry. 2010;10(7):643-61. https://doi.org/10.2174/138955710791384027 https://doi.org/10.2174/138955710791384027; PMid:20500154.

28. Ramos J, David ES, Waing K. G. D. Phytochemical screening and antibacteria testing of different varieties of Morus spp.(Mulberry). Journal of Biological Engineering Research and Review. 2016;3(1):44-8.

29. Clarke G, Ting KN, Wiart Ch, Fry J. High correlation of 2,2-diphenyl-1-picrylhydrazyl (DPPH) radical scavenging, ferric reducing activity potential and tota phenolics content indicates redundancy in use of all three assays to screen for antioxidant activity of extracts of plants from the malaysian rainforest. Antioxidants. 2013;2(1):1-10. doi:10.3390/antiox2010001. https://doi.org/10.3390/ antiox2010001.

30. Windono T, et al. Uji Peredaman Radikal Bebas terhadap DPPH dari Ekstrak Kulit Buah dan Biji Anggur Probolinggo Biru dan Bali. Artikel Hasil Penelitian Artocarpus. 2001;1:34-43

31. Apak $\mathrm{R}$, et al. Comparative evaluation of various total antioxidant capacity assays applied to phenolic compounds with the CUPRAC assay. Molecules. 2007;12(7):1496-47. doi:10.3390/12071496. https://doi.org/10.3390/12071496.

32. Memon AA, et al. Phenolic acids profiling and antioxidant potential of mulberry (Morus laevigata W, Morus nigra L, Morus alba L.) leaves and fruits grown in Pakistan. Polish Journal of Food and Nutrition Sciences. 2010;60(1):

33. Jun $\mathrm{M}$, et al. Comparison of antioxidant activities of isoflavones from kudzu root (Pueraria lobata Ohwi). Journal of Food Science. 2003:68(6):2117-22. DO 10.1111/j.1365-2621.2003.tb07029.x. https://doi.org/10.1111/j.1365-2621.2003. tb07029.x.

\section{HIGHLIGHTS OF PAPER}

- $\quad$ Black mulberry fruit extracts have antibacterial activity with $\mathrm{MIC}$ value of by $2.5 \%$ against the bacteria $S$. epidermis and P. acnes

- $\quad$ Black mulberry fruit extracts have antibacterial activity with $\mathrm{MBC}$ value for each bacterium was $2.5 \%$ and $5 \%$.

- $\quad$ Black mulberry fruit extracts has medium potential antioxidant activity with $\mathrm{IC}_{50}$ value is $146.731 \mathrm{mg} / \mathrm{mL}$.

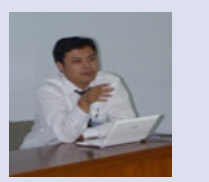

AUTHOR PROFILE

Arif Budiman is a lecturer in Universitas Padjadjaran (UNPAD), Indonesia, in Pharmaceutics and Technology Pharmacy department. Has experience in semisolid formulation from medicinal plants.

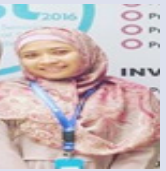

Diah Lia Aulifa: Is a lecturer in Sekolah Tinggi Farmasi Indonesia (STFI), Indonesia, in Biology Pharmacy department. Develop work in Phytochemistry and Phytoteraphy from plants.

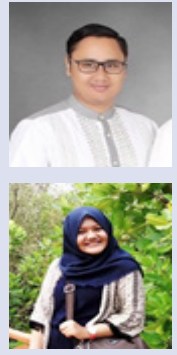

Arif Satria Wira Kusuma: Is a lecturer in Universitas Padjadjaran, Indonesia (UNPAD), in Biology Pharmacy department, in the area concentration microbiology and biotechnology.

Astri Sulastri: Is an undergraduate student of the Pharmacy Course, Universitas Padjadjaran (UNPAD), Indonesia.

Cite this article : Budiman A, Aulifa DL, Kusuma ASW, Sulastri A. Antibacterial and Antioxidant Activity of Black Mulberry (Morus nigra L.) Extract for Acne Treatment. Pharmacog J. 2017;9(5):611-4. 